\title{
Antioxidant and Cytotoxic Properties of Soft Coral Nepthea sp.
}

\author{
Baru Sadarun ${ }^{1}$, Nur Syifa Rahmatika², Agung Wibawa Mahatva Yodha3,4, Adryan Fristiohady3, \\ Andini Sundowo5, Syarul Nataqain Baharum ${ }^{6}$, Sahidin I* $^{*}$ \\ ${ }^{1}$ Faculty of Marine Sciences and Fisheries, Universitas Halu Oleo \\ ${ }^{2}$ Faculty of Medicine, Universitas Halu Oleo \\ ${ }^{3}$ Faculty of Pharmacy, Universitas Halu Oleo \\ Kampus Hijau Bumi Tridharma, Anduonohu, Kec. Kambu, Kota Kendari, Sulawesi Tenggara 93232 Indonesia \\ ${ }^{4}$ Health Polytechnics of Bina Husada \\ Jl. Sorumba, Anaiwoi, Kec. Kadia, Kota Kendari, Sulawesi Tenggara 93117 Indonesia \\ ${ }^{5}$ Research Centre for Chemistry, Indonesia Institute of Sciences \\ Jl. Puspitek Serpong Gate, Serpong, Tangerang Selatan, Banten 15314 Indonesia \\ 6Institute of Systems Biology (INBIOSIS) Universiti Kebangsaan Malaysia \\ 43600, Bangi, Selangor, Malaysia \\ Email: sahidin02@uho.ac.id
}

\begin{abstract}
Soft coral Nepthea sp. grows in the seas of South-East Sulawesi, Indonesia. However, information on the chemical and pharmaceutical aspects of this genus is still limited. Therefore, this research aims to explore the chemical contents and biological activities of Nepthea sp. The sample was collected from the waters of Saponda Island by SCUBA diving. It was extracted by ethyl acetate and fractionated using vacuum liquid chromatography. The chemical content was analyzed by phytochemical screening, LC-MS/MS analysis, Total Phenolics Content and Total Flavonoids Contents. Antioxidant potency was evaluated by DPPH (2,2-diphenyl-1-picrylhydrazyl) radicals and ABTS (2,2'-azino-bis-3-ethylbenzthiazoline-6-sulphonic acid). Cytotoxicity property was analyzed by MTT (3-(4,5Dimethylthiazol-2-yl)-2,5-diphenyltetrazolium bromide) assays. The result showed that the fractionation of Nepthea ethylacetate extracts produced six fractions (A-F). Fractions $A$ and B contain non-polar compounds. Based on LCMS/MS data, the non-polar compounds in Fraction $A$ and $B$ include achillin, atractylenolide II, buthyl isobuthyl phthalate, rengyolester, 2a-acetoxycostic acid, ocotillol acetate, petasitolone and some unidentified compounds that are $\mathrm{C}_{33} \mathrm{H}_{58} \mathrm{O}_{4}, \mathrm{C}_{15} \mathrm{H}_{21} \mathrm{NO}, \mathrm{C}_{21} \mathrm{H}_{33} \mathrm{NO}$, and $\mathrm{C}_{16} \mathrm{H}_{20} \mathrm{O}_{4}$. In general, the antioxidant and cytotoxic properties of all samples are in the weak category, however, when examined for each sample, the antioxidant properties of fraction $B$ is slightly better than fraction $A$ based on the $I C_{50}$ value of DPPH and ABTS. Cytotoxicity of Fraction $A$ is better than Fraction B against Breast Cancer cell lines MCF-7. The non-polar fraction of Nepthea sp. can be developed as raw material for the discovery of new compounds, antioxidant and anticancer agents, especially breast cancer.
\end{abstract}

Keywords: Nepthea sp., non-polar fraction, antioxidant, cytotoxic, South East Sulawesi

\section{Introduction}

Southeast Sulawesi is an archipelagic province, has 651 islands, $74.25 \%$ of its territory is the ocean (Bangwilsultra, 2016). One of the important and abundant marine natural resources is soft coral. In Waworaha Waters, Konawe, with a monitoring area of $700 \mathrm{~m} 2$, eight types of soft coral were found (Wanda et al., 2018). The chemical content and efficacy in the pharmaceutical field have not been reported yet. Even though there are many new compounds from soft corals that have very interesting properties, such as sarcophine from $S$. glaucum growing in the Red Sea is active as a modulator of glycine receptors in the nervous system (Saleh et al., 2020), S. solidum produces diterpene compounds (Zhu et al., 2015), and several terpenoid compounds are also obtained from Lobophytum crasum and oxygenated steroids from $S$. pauciplicatum, can increase the immune system to fight infection of cancer patients (Florean et al., 2020).

Nepthea sp. (Nephtheidae) is one of the soft corals found in Waworaha, It is also considered widespread in the Indo-Pacific region (Seah et al., 2015), Mauritius and Rodrigues Island (Jahajeeah et al., 2021), and the Brazilian Coast (Almeida et al., 2014). Some compounds reported from Nepthea that are tetraprenyl-benzoquinone derivative from Nepthea sp. and a guaiane-based sesquiterpene from N. chabroli (Almeida et al., 2014), nephtoacetal 
from Nepthea sp. is active against HeLa cell lines (Zhang et al., 2013), erectasteroids A-H from $\mathrm{N}$. erecta are cytotoxic against P-388 and HT-29 cell lines (Cheng et al., 2007), nebrosteroids A-H from N. chabroli have potential as anti-inflammation (Huang et al., 2008). The larger scope is the family level, Neptheidae, which has 20 genera, including Nepthea. Several secondary metabolites that have been identified from this family are sesquiterpenes. diterpenes, steroils, and quinones (Almeida et al., 2014). Some of them are paramlemnolin isolated from Paralemnalia thyrsoides (Huang et al., 2005), linardosenenes $A-C$ and lineolimnenes $A-D$ from Litophyton nigrum which active against some human cancer cell lines (Yang et al., 2020), and linardosenenes D-G from L. nigrum were active towards BRD4 (Yang et al., 2021). Dendronepththya rebeola produced acetoxycapnelle-2D,8E,13triacetoxycapnell-9(12)-ene-10D-ol (Grote et al., 2007), flavalin E identified from Lemnia flava (Su et al., 2011) and sclerosteroid J isolated from Scleronephthya gracillimum (Fang et al., 2013).

In continuing our study on chemical and pharmaceutical aspects of marine natural resources, soft coral especially Nepthea sp. was chosen as the research sample. Before research on soft corals, we had worked with sponges and through the process of isolation and structure determination, we obtained a new compound from Chlatria sp, namely Clathruohate, and has been published in MJAS, 2018 (Sahidin et al., 2018), and chemical screening of some sponges (Sahidin et al., 2020). Biological activities of sponges include antihyperlipidemic (Wahyuni et al., 2019), Anti-Inflammatory (Fristiohady et al., 2019), antioxidant properties and acute toxicity (Fristiohady et al., 2020).

Based on the literature review (searching) in Science Direct and Springer Link, no information has been found regarding the study of chemical and pharmaceutical aspects of Nepthea sp. from South East Sulawesi (Indonesia). Soft corals from Indonesia whose chemical and pharmaceutical aspects have been reported include Sinularia depresa from the South China Sea which produces sinulasterol A-C which plays a role in cancer prevention through antiinflammatory effects (Yang et al., 2020) and ethyl acetate and butanol extracts of Lobophytum sp. from Selayar, South Sulawesi, is active as an anti-bacterial and antioxidant (Putra et al., 2016). Meanwhile, the study of soft corals from Southeast Sulawesi is still in the mapping stage (Pedoja et al., 2018). This article explains the study of antioxidant and toxicity against breast cancer cells lines (MCF-7) as well as the study of the chemical content using LC-MS/MS of the nonpolar fraction of soft coral Nepthea sp. that grows in Southeast Sulawesi.

\section{Materials and Methods}

\section{General procedures}

A Waters Acquity UPLC I-Class was used in conjunction with a Xevo G2-X2 Quadrupole Time-ofFlight (QToF) mass spectrometer to perform the LCMS/MS study. Methanol, ethyl acetate, and n-hexane are among the chemicals used, and the aquades are of analytical quality.Thin-layer chromatography plate: Kieselgel $60 \mathrm{~F}_{254}$ 0,25 mm (Merck), silica gel $60 \mathrm{GF}_{254}$ p.a (Merck $\left.{ }^{\circledR}\right)$, silica $60 \mathrm{G}\left(\right.$ Merck $\left.^{\circledR}\right)$, cerium sulphate $\left(\mathrm{CeSO}_{4}\right)\left(\mathrm{Merck}^{\circledR}\right)$, ascorbic acid $\left(\right.$ Merck $\left.^{\circledR}\right)$, gallic acid $\left(\right.$ Merck $\left.^{\circledR}\right)$, quercetin (Merck $\left.{ }^{\circledR}\right)$, doxorubicin (Merck ${ }^{\circledR}$ ), DPPH (2,2-diphenyl-1-picrylhydrazyl), ABTS (2,2'-azino bis-3-ethylbenzthiazoline-6-sulphonicacid) Merck $\left.^{\circledR}\right)$, and MTT (3-(4,5-Dimethylthiazol-2-yl)-2,5-diphenyltetrazolium bromide) $\left(\right.$ Merck $\left.^{\circledR}\right)$.

\section{Nepthea sp. collection}

The sample was taken on the reef slopes of the Saponda Islands in Indonesia's Province of Southeast Sulawesi. SCUBA diving at a depth of 4-10 m was used to collect the sample. The material was collected and put in separate ice containers before being returned to the laboratory for further analysis.

\section{Extraction and fractionation}

Fresh Nepthea sp. (3 kg) samples were chopped into small pieces and extracted in ethyl acetate $(3 \times 10 \mathrm{~L}, 24 \mathrm{~h}$ each time $)$ at room temperature. Each dried soft coral extract was collected under reduced pressure and stored at $4{ }^{\circ} \mathrm{C}$ for future analysis in an amber bottle. The ethyl acetate extract (160 g) was fractionated using Vacuum Liquid Chromatography (VLC) with silica gel as an adsorbent and a combination of $n$-hexane: ethyl acetate (100:0 up to 0:100\%) and methanol 100 per cent as eluent, yielding six fractions (A-F).

\section{Phytochemical screening}

The presence of alkaloids, flavonoids, tannins, terpenoids, steroids, and saponins in the selected sponges was determined using phytochemical screening methods (Harborne, 1973).

\section{Total Phenolics Content (TPC) and Total Flavonoids Content (TFC)}

The TPC of the samples were determined using the Folin and Ciocalteu reagent, following Singleton and Rossi's method with minor adjustments and the total flavonoids of the samples were determined using Chang et al's (Chandra et al., 2014). The nonpolar fraction of the soft coral Nepthea sp. was prepared for LC-MS/MS analysis using the standard 
operating procedure of this instrument (Sahidin et al., 2020). Antioxidant assay of the samples was assessed using the DPPH radical (Sahidin et al., 2020). The modified Moniruzzaman method was used for ABTS Assay (Wahyuni et al., 2021). The MTT (3-(4,5-dimethylthiazol-2-yl)-2,5-diphenyltetrazolium bromide) assay was used to assess cytotoxicity in MCF-7 cells in vitro (Asasutjarit et al., 2021).

\section{Result and Discussion}

Vacuum Liquid Chromatography with silica gel as an adsorbent and a solvent mixture of n-hexane: ethyl acetate (100\%:0 \% up to 0\%:100\%) followed by methanol was used to fractionate ethyl acetate extract, to give six fractions (A-F). Fraction $A$ and $B$ have interesting TLC chromatogram patterns after being developed by $n$-hexane : ethyl acetate $=8: 2$ as eluent (Figure 1.), and also have sufficient weight for further experiments such as biological activity tests or isolation of nonpolar compounds, $35.5 \mathrm{~g}$ of $\mathrm{A}$ and $\mathrm{B}=$ $4.3 \mathrm{~g}$, respectively (Tabel 1.).

Table 1 shows that the ethyl acetate extract contains saponins, tannins, alkaloids and terpenoids, while fractions $A$ and $B$ only contain terpenoids. Because of fractions, $A$ and $B$ are the non-polar fraction, so that the compounds in the two fractions are non-polar. This phenomenon can also be observed from the Retardation factor (Rf) values of fractions $A$ and $B$ which are higher than the other fractions and also become the place where the top (non-polar) part of the ethyl acetate extract (T) TLC chromatogram is concentrated. The absence of polar compounds such as flavonoids, saponins, tannins, alkaloids and other phenolics in Fraction A and B can be seen from the value of TPC and TFC, where TPC and TFC of fractions $A$ and $B$ are 0.0 mgGAE.g Ex ${ }^{-1}$ and 0.0 mgQE. g Ex ${ }^{-1}$ respectively. This means that the polar portion of the ethyl acetate extract is stored in the other fraction. The presence of non-polar compounds from the non-polar fraction of Nepthea sp. is relevant with the compounds previously found from Nepthea sp. (Coll et al., 1985).

An in-depth study of the compounds of the non-polar fraction of Nepthea sp. ethyl acetate extract can be clearly explained based on the data from the LC-MS/MS analysis in Table 2 and Figure 2. Ethyl acetate extract has ten compounds and five of them has been identified, Fraction A has five compounds and seven compounds of Fraction B. Generally, all of the identified compounds are terpenoids consisting of monoterpenes (compound 3), sesquiterpenes $(1,2,4,5,6,7,8,10)$ and steroids (9), which matches the previous invention (Almeida et al., 2014; Florean et al., 2020; Saleh et al., 2020).

An interesting phenomenon is the presence of nitrogenous compounds in the non-polar fraction. Usually, nitrogenous compounds in secondary metabolites are alkaloids which are semi-polar up to polar compounds. It is presumed that the alkaloids are found in the form of free nitrogen and not in the form of nitrogen salts. The use of this fractionation method can describe the diversity of compounds in the non-polar fraction of Nepthea sp., it will also make it easier to carry out the next step, namely the isolation and elucidation of non-polar compounds from Nepthea sp.
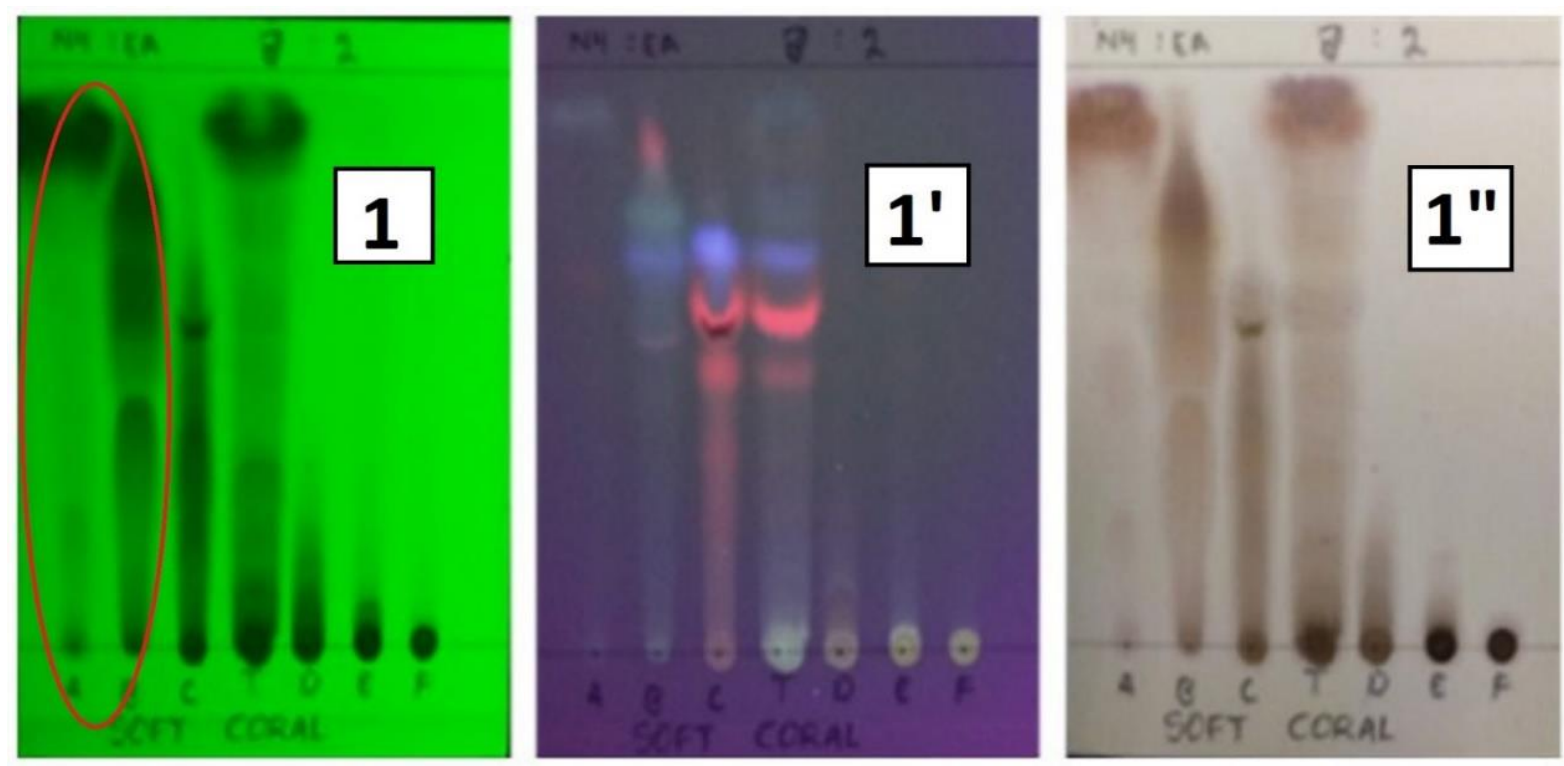

Figure 1. TLC Chromatogram of ethylacetate extract (T) and the fraction A-F Note: 1 = at $\lambda 254 \mathrm{~nm}$ (short); $1^{\prime}=\lambda 366 \mathrm{~nm}$ (long); $1^{\prime \prime}=\mathrm{CeSO}_{4}+$ heat 
The biological activity of all samples will be clearer and more interesting when presented in Table 3 and graphical form in Figure 3. Antioxidant activity is represented by the $\mathrm{IC}_{50}$ value of DPPH and ABTS. Cytotoxicity of samples was evaluated against breast cancer cell lines MCF-7.

Based on the $\mathrm{IC}_{50}$ value of DPPH and ABTS of all samples in the Table 3 , the $\mathrm{IC}_{50}$ value of all samples is $>150 \mathrm{ppm}\left(\mathrm{mgL}^{-1}\right.$ ) or in other words the antioxidant properties of all samples are in the weak category (Tristantini et al., 2016). The study for each sample shows that fractions $A$ and $B$ have antioxidant potential better than ethyl acetate extract. Although the ethyl acetate extract contains phenolic and flavonoid compounds which are indicated by the TPC and TFC values as listed in Table 3, the diversity and solubility of the compounds, as well as the mole fraction of non-TPC and non-TFC compounds, greatly affect the antioxidant power of the ethyl acetate extract. Furthermore, the antioxidant properties of fraction $B$ were slightly better than fraction $A$, both based on the $\mathrm{IC}_{50} \mathrm{DPPH}$ and ABTS values. This fact is supported by differences in compound content. Fraction $B$ has compounds that have been identified LC-MS/MS consisting of 1,9 and 10 while fraction A contains 6,7 and 8 . Compounds 1,9 and 10 contain hydroxyl units, so it is easier to donor hydrogen radicals than compounds 6,7 and 8 . In other words, the compounds in Fraction $B$ are easier to donate proton radicals or are easier to neutralize radicals or have stronger antioxidant properties.

Table 1. Weight, chemical profiles and biological activities of the samples

\begin{tabular}{lccc}
\hline & Ethyl acetate macerate & \multicolumn{2}{c}{ Fraction } \\
\cline { 3 - 4 } & & $\mathrm{A}$ & $\mathrm{B}$ \\
\hline Weight (g) & 160.0 & 35.2 & 4.3 \\
Flavonoids & - & - & - \\
Saponins & + & - & - \\
Tannins/ Phenolics & + & - & - \\
Alkaloids & + & - & - \\
Terpenoids & + & + & + \\
TPC (mgGAE.g Ex & -1 ) & 0 & 0 \\
TFC (mgQE. g Ex-1) & $23.9 \pm 0.87$ & 0 & 0 \\
\hline
\end{tabular}<smiles>C=C(C(=O)O)C1CC[C@]2(C)C[C@H](OC(C)=O)CC(=C)[C@]2(C)C1</smiles>

$2 \alpha$-acetoxycostic acid (1)<smiles>CC1=C2C(C)(C)CC(O)C3C(C)C(=O)OC23C(C)C1=O</smiles>

Artemisin (2)<smiles>CC1(C)CC(O)CC2(C)OC(=O)C=C12</smiles>

Digiprolactone (3)<smiles>C=C(C)C1CCC2=CC(=O)CC(C)C2(C)C1</smiles>

Nootkatone (4)<smiles>O=C(Cc1ccc(O)cc1)OCCC1(O)CCC(O)CC1</smiles>

Rengyolester (5)<smiles>CC1=CC(=O)C2=C(C)CC[C@H]3[C@H](C)C(=O)O[C@H]3[C@H]12</smiles>

Achillin (6)

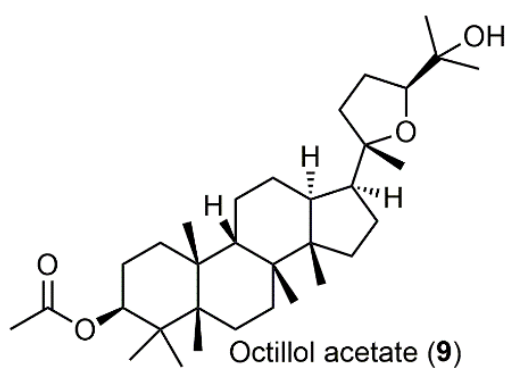<smiles>C[C@H]1CCC[C@H]2CC(=O)C(C(C)(C)O)=C[C@]12C</smiles>

Petasitolone (10)<smiles>CCCCOC(=O)c1ccccc1C(=O)OCC(C)C</smiles>

Butyl-isobutyl phthalate (8)

Figure 2. Identified compounds of ethyl acetate extract, fraction A and B 
ILMU KELAUTAN: Indonesian Journal of Marine Sciences March 2022 Vol 27(1):29-36

Table 2. Chemical profile of ethyl acetate extract, Fraction A and B based on LC-MS/MS data

\begin{tabular}{|c|c|c|c|c|c|c|}
\hline \multirow[t]{2}{*}{$\cdot g \mathrm{Ex}^{-1}$} & \multicolumn{6}{|c|}{ g Ex-1 } \\
\hline & . $g \mathrm{Ex}^{-1}$ & Ethylacetate Extract & Rt (min) & Fraction A & Rt (min) & Fraction B \\
\hline$\cdot g \mathrm{Ex}^{-1}$ & $\cdot g \mathrm{Ex}^{-1}$ & 2a-Acetoxycostic acid & & - & 10.44 & 2a-Acetoxycostic acid \\
\hline g $\mathrm{Ex}^{-1}$ & $\cdot g \mathrm{Ex}^{-1}$ & Artemisinin & & - & & - \\
\hline$g \mathrm{Ex}^{-1}$ & $g \mathrm{Ex}^{-1}$ & Digiprolactone & & - & & - \\
\hline$\cdot g \mathrm{Ex}^{-1}$ & $\cdot g \mathrm{Ex}^{-1}$ & Nootkatone & & - & & - \\
\hline$\cdot g \mathrm{Ex}^{-1}$ & $\cdot g \mathrm{Ex}^{-1}$ & Rengyolester & 10.21 & Rengyolester & 7.91 & rengyolester \\
\hline$g \mathrm{Ex}^{-1}$ & $g \mathrm{Ex}^{-1}$ & - & 10.16 & Achillin & & - \\
\hline$\cdot g \mathrm{Ex}^{-1}$ & $\cdot g \mathrm{Ex}^{-1}$ & - & 10.45 & Atractylenolide II & & - \\
\hline$\cdot g \mathrm{Ex}^{-1}$ & $\cdot g \mathrm{Ex}^{-1}$ & - & 10.35 & Buthyl isobuthyl phthalate & & - \\
\hline$g \mathrm{Ex}^{-1}$ & $g \mathrm{Ex}^{-1}$ & - & & - & 12.61 & Ocotillol acetate \\
\hline$\cdot g \mathrm{Ex}^{-1}$ & $\cdot g \mathrm{Ex}^{-1}$ & & & - & 6.64 & Petasitolone \\
\hline g $\mathrm{Ex}^{-1}$ & g $\mathrm{Ex}^{-1}$ & Candidate Mass $\mathrm{C}_{15} \mathrm{H}_{21} \mathrm{NO}$ & & - & 10.37 & $\mathrm{C}_{15} \mathrm{H}_{21} \mathrm{NO}$ \\
\hline$g \mathrm{Ex}^{-1}$ & $g \mathrm{Ex}^{-1}$ & Candidate Mass $\mathrm{C}_{21} \mathrm{H}_{33} \mathrm{NO}_{2}$ & & - & 10.74 & $\mathrm{C}_{21} \mathrm{H}_{33} \mathrm{NO}$ \\
\hline$\cdot g \mathrm{Ex}^{-1}$ & $\cdot g \mathrm{Ex}^{-1}$ & Candidate Mass $\mathrm{C}_{16} \mathrm{H}_{22} \mathrm{O}_{6}$ & & - & & - \\
\hline$\cdot g \mathrm{Ex}^{-1}$ & g $\mathrm{Ex}^{-1}$ & Candidate Mass $\mathrm{C}_{15} \mathrm{H}_{23} \mathrm{NO}_{3}$ & & - & & - \\
\hline$\cdot g \mathrm{Ex}^{-1}$ & $\cdot g \mathrm{Ex}^{-1}$ & Candidate Mass $\mathrm{C}_{54} \mathrm{H}_{78} \mathrm{O}_{9}$ & & - & & - \\
\hline$g \mathrm{Ex}^{-1}$ & $g \mathrm{Ex}^{-1}$ & - & 11.96 & $\mathrm{C}_{33} \mathrm{H}_{58} \mathrm{O}_{4}$ & & - \\
\hline g $\mathrm{Ex}^{-1}$ & . g Ex-1 & - & & - & 10.24 & $\mathrm{C}_{16} \mathrm{H}_{20} \mathrm{O}_{4}$ \\
\hline
\end{tabular}

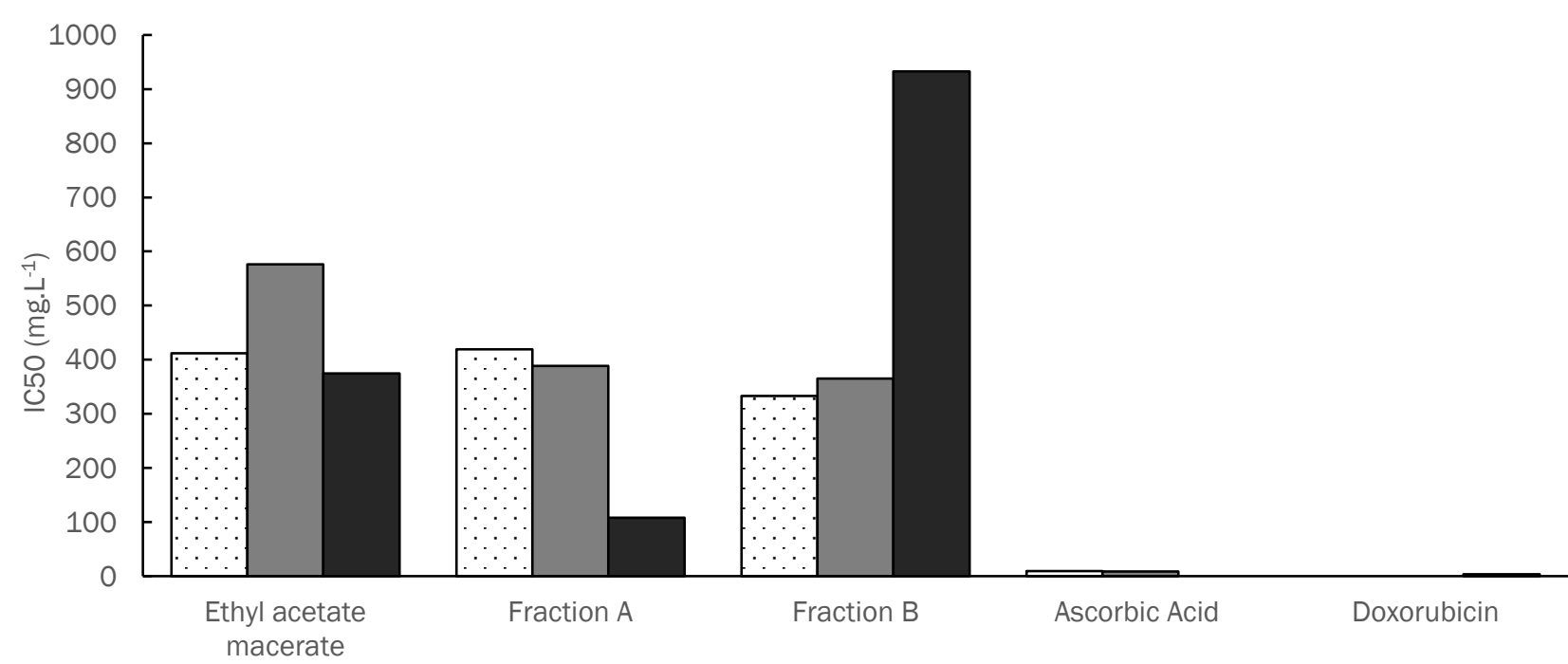

口DPPH $\square$ ABTS $\square$ MCF-7

Figure 3. Biological activities of the samples

Table 3. Antioxidant and cytotoxic properties of the samples

\begin{tabular}{|c|c|c|c|c|c|}
\hline & \multirow{2}{*}{$\begin{array}{c}\text { Ethyl acetate } \\
\text { macerate }\end{array}$} & \multicolumn{2}{|c|}{ Fraction } & \multicolumn{2}{|c|}{ Standard (positive control) } \\
\hline & & A & B & Ascorbic Acid & Doxorubicin \\
\hline DPPH (IC 50 in mg.L-1) & $412.01 \pm 5.78$ & $491.41 \pm 4.22$ & $333.26 \pm 2.41$ & $9.58 \pm 0.57$ & \\
\hline ABTS (IC 50 in mg. $\left.\mathrm{L}^{-1}\right)$ & $576.30 \pm 3.62$ & $388.76 \pm 2.64$ & $364.87 \pm 2.74$ & $8.84 \pm 0.69$ & \\
\hline MCF-7 (IC50 in mg.L-1) & $374.97 \pm 31.80$ & $107.81 \pm 6.40$ & $932.96 \pm 58.63$ & & $3.40 \pm 0.25$ \\
\hline
\end{tabular}

Ethylacetate extract and Fraction A have cytotoxic potential against breast cancer cells lines (MCF-7), although their activities are weaker than that positive control. Based on the level of cytotoxicity
(Weerapreeyakul et al., 2012) that the extract is categorized as very active if it has $\mathrm{IC}_{50}<10 \mathrm{mg} \cdot \mathrm{mL}^{-1}$, active (10-100 mg. $\mathrm{mL}^{-1}$ ), moderately active (100-500 $\left.\mathrm{mg} \cdot \mathrm{mL}^{-1}\right)$, then ethylacetate extract and fraction $A$ 
were categorized as moderately active. For the samples, the cytotoxic properties of Fraction A had better cytotoxic properties than the ethylacetate extract and Fraction B. Furthermore, the ethyl acetate extract was stronger than the fraction $\mathrm{B}$. This phenomenon is still quite difficult to explain. However, when looking at the structure of the standard compound (positive control) in this study, namely doxorubicin, and the active compound used in the treatment of breast cancer (tamoxifen) (Thayyib et al., 2020), both compounds are alkaloids. Doxorubicin and tamoxifen have structural formulas $\mathrm{C}_{27} \mathrm{H}_{29} \mathrm{NO}_{11}$ and $\mathrm{C}_{26} \mathrm{H}_{29} \mathrm{NO}$, respectively.

\section{Conclusion}

The non-polar fraction of Nepthea sp. ethyl acetate extract has interesting potential for both the diversity of compounds and their biological activities. The compounds in the non-polar fraction based on LC-MS/MS data include achillin, atractylenolide II, buthyl isobuthyl phthalate, rengyolester, 2aacetoxycostic acid, ocotillol acetate, petasitolone and some unidentified compounds. Furthermore, the nonpolar fraction can be further developed as raw material for the discovery of new compounds, antioxidant and anticancer agents, especially breast cancer.

\section{Acknowledgement}

The Ministry of Education, Culture, Research, and Technology of the Republic of Indonesia supported the project with a research grant under the scheme of the Penelitian Dasar Unggulan Perguruan Tinggi (PDUPT) 2021, contract No. 21/UN29.20 /PG/2021.

\section{References}

Almeida, M.T.R., Moritz, M.I.G., Capel, K.C., Pérez, C.D. \& Schenkel, E.P. 2014. Chemical and biological aspects of octocorals from the Brazilian coast. Rev. Bras. Farmacogn., 24: 446467.

Asasutjarit, R., Sooksai, N., Fristiohady, A., Lairungruang, K., Ng, S.F., \& Fuongfuchat, A. 2021. Optimization of Production Parameters for Andrographolide-Loaded Nanoemulsion Preparation by Microfluidization and Evaluations of Its Bioactivities in Skin Cancer Cells and UVB Radiation-Exposed Skin. Pharmaceutics, 13(8): p1290. https://doi.org/10.3390/pharmaceuti cs13081290.

Bangwilsultra, 2016. Profil Sulawesi Tenggara. https://bangwilsultrablog.wordpress.com/2016 /05/29/sulawesi-tenggara/
Chandra, S., Khan, S., Avula, B., Lata, H., Yang, M.H., El-Sohly, M.A. \& Khan, I.A. 2014. Assessment of Total Phenolic and Flavonoid Content, Antioxidant Properties, and Yield of Aeroponically and Conventionally Grown Leafy Vegetables and Fruit Crops: A Comparative Study. J. Evid. Based Complementary Altern. Med., Article ID 253875: 1-10. https://doi. org/10.1155/2014/253875

Cheng, S., Dai, C. \& Duh, C. 2007. New 4-methylated and 19-oxygenated steroids from the Formosan soft coral Nepthea erecta. Steroids, 72: 653659. https://doi.org/10.1016/j.steroids.2007. 05.001

Fang, H.Y., Hsu, C.H., Chao, C.H., Wen, Z.H., Wu, Y.C., Dai, C.F. \& Sheu, J.H. 2013. Cytotoxic and Antiinflammatory Metabolites from Soft Coral Scleronephya gracillimum. Mar. Drugs. 11: 1853-1865. https://doi.org/10.3390/md11061 853.

Florean, C., Dicato, M. \& Diederich, M. 2020. Immune-modulating and anti-inflammatory marine compounds against cancer. Seminars in Cancer Biology In Press. https://doi.org/10.10 16/j.semcancer.2020.02.008

Fristiohady, A., Wahyuni, Malik, F., Purnama, L.O.M.J. \& Sahidin, I. 2019. Anti-Inflammatory Activity of Marine Sponge Callyspongia Sp. and Its Acute Toxicity. Asian J. Pharm. Clin. Res., 12(12): $97-$ 100. https://doi.org/10.22159/ajpcr.2019.v1 $2 \mathrm{i} 12.34737$

Fristiohady, A., Sadrun, B., Wahyuni, Malaka, M.H., Ahmad, F., Malik, F., Purnama, L.O.M.J. \& Sahidin, I. 2020. Isolation and Identification of Secondary Metabolite Acetone Extract Aaptos sp. and its Antioxidant properties and Acute Toxicity. J. Appl. Pharm. Sci., 10(6): 081-089. https://doi.org/10.7324/JAPS.2020.10611.

Grote, D., Hanel, F., Dahse, HM. \& Seifert, K. 2007. Capnellenes from the soft coral Dendronephya rubeola. Chem. Biodivers. 4: 1683-1693. https://doi.org/10.1002/cbdv.200890157

Harborne, J.B. 1973. Phytochemical Methods, A Guide to Modern Techniques of Plant Analysis, Chapman and Hall, London.

Huang, H.C., Chao, C.H., Liao, J.H., Chiang, M.Y., Dai, C.F., Wu, Y.C. \& Sheu, J.H. 2005. A Novel Chlorinated Norsesquiterpeneoid and Two Related New Metabolite from Soft Coral Paralemnalia thyrsoides. Tetrahedron Lett. 46: 7711-7714. https://doi.org/10.1016/j.tetlet. 2005.09.027 
Huang, Y., Wen, Z., Wang, S., Hsu, C. \& Duh, C. 2008. New anti-inflammatory 4-methylated steroids from the Formosan soft coral Nepthea chabroli., Steroids, 73: 1181-1186. https://doi.org/10. 1016/j.steroids.2008.05.007

Jahajeeah, D., Bhoyroo, V. \& Ranghoo-Sanmukhiya M. 2021. An assessment of soft coral community (Octocorallia; Alcyonacea) around Mauritius and Rodrigues Island - New record of soft coral. Reg. Stud. Mar. Sci., 47: p101976. https://doi.org/ 10.1016/j.rsma. 2021.101976

Pedoja, K., Husson, L., Bezos, L., Pastier, A.W. \& Imran, A.M. 2018. On the long-lasting sequences of coral reef terraces from SE Sulawesi (Indonesia): Distribution, formation, and global significance. Quat. Sci. Rev., 188: 3757. https://doi.org/10.1016/j.quascirev.2018. 03.033

Putra, M.Y., Murniasih, T., Swasono, R.T., Wibowo, J.T., Saputri, A.N.C., Widhiana, M.R., \& Arlyza, I.S. 2016. Secondary metabolites and their biological activities in Indonesian soft coral of the genus Lobophytum. Asian Pac. J. Trop. Biomed., 6(11): 909-913. https://doi.org/10. 1016/j.apjtb.2016.08.011

Sahidin, I., Sabandar, C.W., Wahyuni, Hamsidi, Malaka, M.H, Sadarun, B. \& Aslan, L.O. 2018. ANor Sterols from an Indonesian Marine Sponge, Clathria Species. Malaysian J. Anal. Sci., 22(3): 375-82. https://doi.org/10.17576/ mjas-20182203-02.

Sahidin, I., Sabandar, C.W., Wahyuni, Hamsidi, R., Mardikasari, S.A., Zubaydah, W.O.S., Sadarun, B., Musnina, W.O.S, Darmawan, A. \& Sundowo, A. 2020. Investigation of Compounds and Biological Activity of Selected Indonesian Marine Sponges, Nat. Prod. J., 10(3): 312-321. https://doi.org/10.2174/221031550966619 0627105237

Saleh, H.A., Raafat, K.M., Temraz, T.A., Noureldin, N., Breitinger, H.G. \& Breitinger, U. 2020. Sarcophine and (7S, 8R)-dihydroxydeepoxysarcophine from the Red Sea soft coral Sarcophyton glaucum as in vitro and in vivo modulators of glycine receptors. Neurotoxicology, 80: 105-111. https://doi.org/10.1016/j.neuro. 2020.07.002.

Seah, J..ZS., Yap, N.W.L., Tan, LT. \& Goh, B.P.L. 2015. Distribution and abundant of octocoral (Octocorallia, Alcyonacea) communities at three Southern Island of Singapore. Ocean Sci. J.
50(2): 299-306. https://doi.org/10.1007/s12 601-015-0027-z

Su, J.H., Lu, Y., Hung, W.Y., Huang, C.Y., Chiang, M.Y., Sung, P.Y., Kuo, Y.H. \& Sheu, J.H. 2011. Sesquiterpenoids from the Formosan Soft Coral Lemnalia Flava. Chem. Pharm. Bull. 59: 698702. https://doi.org/10.1248/cpb.59.698.

Thayyib, H., Muis, M. \& Murtala, B. 2020. Gambaran ultrasonografi kelainan endometrium pada penderita kanker payudara yang mendapat terapi hormonal di Rumah Sakit Wahidin Sudirohusodo. Nusantara Medical science Journal, 5(2): 13408. https://doi.org/10.209 56/nmsj.v5i2.13408.

Tristantini, D., Ismawati, A., Pradana, B.T. \& Jonathan, J.G. 2016. Pengujian aktivitas antioksidan menggunakan Metode DPPH pada daun Tanjung (Mimusops elingi L.), Prosiding Seminar Nasional Kimia "Kejuangan", Yogyakarta, 17 Maret 2016

Wahyuni, Diantini, A., Ghozali, M., Subarnas, A., Julaeha, E., Amalia, R. \& Sahidin, I. 2021. Phytochemical screening, toxicity activity, and antioxidant capacity of ethanolic extract of Etlingera alba rhizomes. Pak. J. Biol. Sci., 24: 807-814. https://doi.org/10.3923/pjbs.2021. 807.814

Wahyuni, Fristiohady, A., Malaka, M.H., Malik, F., Yusuf, M.I., Leorita, M., Sadarun, B., Saleh, A., Musnina, W.O.S., Sabandar, C.W. \& Sahidin, I. 2019. Effects of Indonesian Marine Sponges Ethanol Extracts on the Lipid Profile of Hyperlipidemic Rats. J. Appl. Pharm. Sci., 9(10): 001-008. https://doi.org/10.7324/JAPS.2019. 91001

Wanda, E., Sadarun, B. \& Rahmadani. 2018. Keanekaragaman dan kepadatan karang lunak di perairan Waworaha Kecamatan Soropia. Sapa Laut, 3(1): 9-15. https://doi.org/10.337 72/jsl.v3i1.6504

Weerapreeyakul, N., Nonpunya, A., Barustux, S., Thitimetharoch, T. \& Sripanidkulchai, B. 2012. Evaluation of the anticancer potential of six herbs against a hepatoma cell lines. Chinese Med. J., 7(15): 1-7. https://doi.org/10.1186/ 1749-8546-7-15.

Yang, F., Li, S.W., Zhang, J., Liang, L.F., Lu, Y.H. \& Gou, Y.W. 2020. Uncommon nordasinane, seconeolemnane and related sesquiterpenoids from Xista soft coral Litophyton nigrum. Bioorg. Chem. 96: p103636. https://doi.org/10.10 16/j.bioorg.2020.103636 
Yang, F., hua, Q., Li, Y., Liang, L.F., Lu, Y.H., An, F. \& Gou, Y.W. 2021. Further new nardosinane-type sesquiterpenoids from Xista soft coral Litophyton nigrum, Fitoterapia, 151: p104906. https://doi.org/10.1016/j.fitote.2021.104906

Yang, M., Cui, X., Li, H., Li, S.W., Yao, L.G., Tang, W., Mudianta, I.W. \& Guo, Y.W. 2020. Sinulasterols A-C, three new bioactive oxygenated steroids from the South China Sea soft coral Sinularia depressa, Steroids, 157: p08598. https:// doi.org/10.1016/j.steroids.2020.108598

Zhang, J., Li, L., Wang, K., Liao, X., Deng, Z. \& Xu, S. 2013. Pentacyclic hemiacetal sterols with antifouling and cytotoxic activities from soft coral Nepthea sp. Bioorganic Med. Chem. Lett., 23: 1079-1082. https://doi.org/10.1016/j. bmcl. 2012.12.012. 